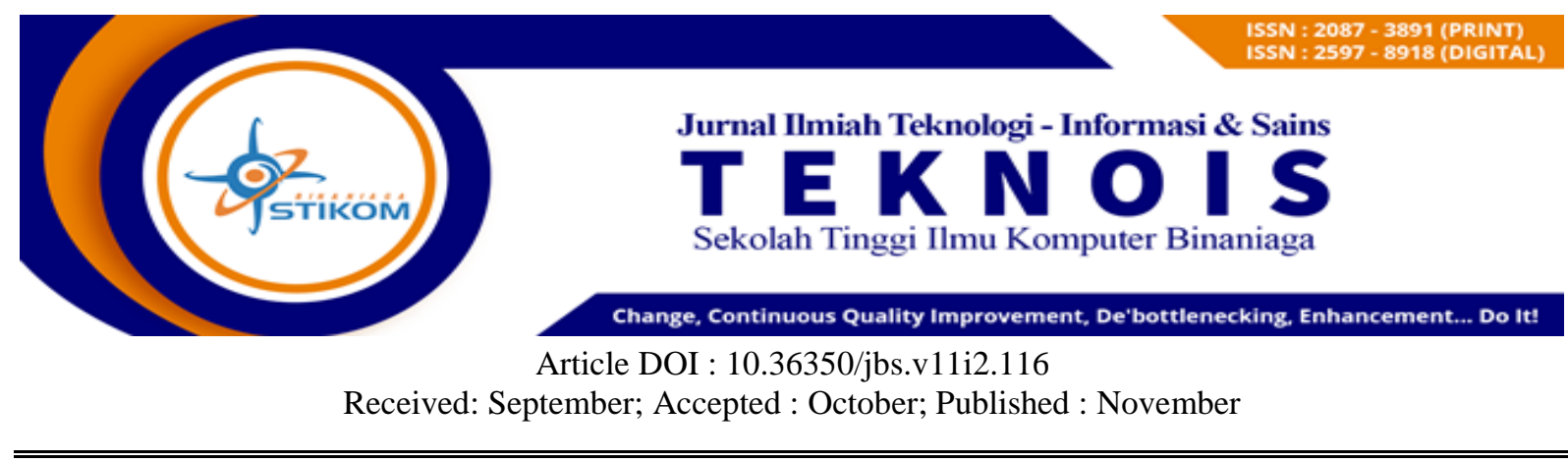

\title{
Rekomendasai Tenaga Pengajar Pada Sekolah TK Nasional Plus Dengan Menggunakan Metode Simple Additive Weighting (SAW)
}

\author{
Dini Erlita ${ }^{1^{*}}$, Lis Utari ${ }^{2}$ \\ ${ }^{1}$ Sistem Informasi/Universitas Binaniga Indonesia \\ Email: dinierlita@gmail.com \\ ${ }^{2}$ Sistem Informasi/ Universitas Binaniga Indonesia \\ Email: lis_utari@yahoo.com
}

\begin{abstract}
In accepting teachers, each school will offer various criteria for prospective teachers. The process of accepting teachers at the Kinderfield Cibinong School is still done manually, where a file selection and comparison with existing criteria will be carried out. Based on the 8 (eight) criteria obtained from interviews with the principal, the weight value of each criterion is also obtained. The application of the method Simple Additive Weighting (SAW) to this problem is one of the most appropriate and effective ways. The existence of a system for the recommendation of teaching staff in national kindergarten schools plus will be more effective and efficient in its use. For the implementation of the system, the compiler uses the vb.net programming language and SQL Server as the database. With the Decision Support System, it can help in determining which prospective teachers will be accepted and the process will be faster.
\end{abstract}

Keywords: Decision Support System; SAW; Recommendation; Criteria; effective.

\section{ABSTRAK}

Dalam penerimaan guru setiap sekolah akan menawarkan kriteria calon guru yang beragam. Proses penerimaan guru di sekolah Kinderfield Cibinong masih dilakukan secara manual, dimana akan dilakukan seleksi file dan membandingkan dengan kriteria yang ada. Berdasarkan 8 (delapan) kriteria yang diperoleh dari wawancara dengan kepala sekolah maka didapat pula nilai bobot dari setiap kriterianya. Penerapan metode Simple Additive Weighting ( $S A W$ ) pada permasalahan ini merupakan salah satu cara yang paling tepat dan efektif. Adanya sebuah sistem untuk rekomendasi tenaga pengajar di sekolah TK nasional plus akan menjadi lebih efektif dan efisien dalam penggunaannya. Untuk implementasi sistem, penyusun menggunakan bahasa pemrograman vb.net dan SQL Server sebagai databasenya. Dengan adanya Sistem Pendukung Keputusan dapat membantu dalam menentukan calon pengajar yang akan diterima dan prosesnyapun akan lebih cepat.

Keywords: Sistem Pendukung Keputusan; SAW; Rekomendasi; Kriteria; Efektif.

\section{A. PENDAHULUAN}

\section{Latar Belakang}

Pendidikan pada saat ini merupakan hal yang penting dikarenakan dengan pendidikan yang tepat, maka kita akan mendapatkan pekerjaan yang kita inginkan. Pendidikan saat ini menjadi 
salah satu kebutuhan hidup yang tak jauh beda dengan kebutuhan akan makan dan minum. Oleh karena itu, sekolah terbaiklah yang diinginkan para orangtua agar anak - anak mereka dapat menghadapi tantangan globalisasi yaitu dengan menyekolahkan anak - anak mereka di sekolah yang memiliki kurikulum internasional. Hingga berdirilah pendidikan yang disebut sekolah nasional plus. Sekolah nasional plus adalah sekolah yang menggunakan kurikulum nasional sekaligus mengadopsi kurikulum yang diakui secara internasional, misalnya kurikulum International Baccalaureate (IB) dan Cambridge International Examinations $(C I E)$. Kelebihan dari sekolah nasional plus adalah memberikan pengalaman kepada para murid untuk berbicara dalam bahasa Inggris.

Di dalam suatu sekolah, tenaga pengajar adalah yang terpenting dalam suatu sekolah dan untuk kelancaran belajar mengajar, suatu sekolah harus memiliki staf pengajar yang berkualitas. Untuk itu, pihak sekolah selalu memiliki kriteria-kriteria tertentu dalam perekrutan tenaga pengajar. Dalam proses perekrutan tenaga pengajar di sekolah nasional plus, awalnya sekolah akan mengecek surat lamaran yang ada di $e$-mail atau diantar melalui pos ke sekolah, kemudian akan memanggil para calon pengajar dimana nantinya mereka akan mengikuti serangkaian tes seperti tes wawancara, tes tertulis, dan beberapa tes lainnya untuk melihat keterampilan dan pribadi calon pelamar tersebut yang semuanya dilakukan dalam dan dengan menggunakan bahasa Inggris. Hasil tes dari para calon pelamar disimpan sebagai arsip dan nantinya yang dipilih sebagai tenaga pengajar baru akan di telepon oleh pihak sekolah. Berdasarkan sistem penerimaan guru yang berjalan saat ini pihak sekolah masih mengalami kesulitan dalam menyeleksi dan mengevaluasi calon pengajar yang berkompeten dikarenakan masih mengandung unsur subjektif terlebih apabila kemampuannya tidak jauh dari calon lain.

Dalam penerimaan tenaga pengajar baru diperlukan beberapa kriteria yang dipertimbangkan. Oleh karena itu, dibutuhkan sistem yang dapat membandingkan tingkat kecocokan untuk setiap kriteria dimana penyusun membangun sebuah sistem pendukung keputusan dengan menggunakan metode Simple Additive Weighting ( $S A W)$. Alasan memilih metode $S A W$ karena metode ini dapat diterapkan di aktivitas publik seperti melakukan penyeleksiaan pegawai baru dengan waktu yang lebih singkat. Penerimaan tenaga pengajar baru termasuk dalam permasalahan Multiple Criteria Decision Making karena terdapat lebih dari satu pilihan untuk memenuhi kriteria tersebut dimana salah satu metodenya adalah Simple Additive Weighting $(S A W)$ yang merupakan salah satu metode model matematis yang dapat digunakan untuk mengambil keputusan. Adapun metode $S A W$ yang pernah juga dipakai oleh jurnal rujukan yaitu (Manik, 2015). Perbedaan penelitian ini dengan penelitian penyusun adalah pada jumlah dan jenis kriterianya.

\section{Permasalahan}

Pada penelitian ini, telah dilakukan wawancara dan mengajukan pertanyaan yaitu kepada kepala sekolah dan staf sekolah dalam 4 (empat) sekolah tk nasional plus. Dari hasil wawancara mereka hampir memiliki permasalahan yang sama dalam penentuan tenaga pengajar yang akan diterima apabila ada 2 (dua) calon pelamar yang nilainya sama. Hasil penilaian kurang optimal dikarenakan tidak adanya bobot dalam penilaian dari kriteria-kriteria tersebut.

Berdasarkan hal tersebut maka identifikasi masalah dalam penelitian ini adalah :

a. Belum tepat dalam menentukan tenaga pengajar mana yang dipilih dimana pelamar yang telah dipilih kinerjanya tidak sesuai dengan yang diharapkan.

b. Belum efektif dalam proses penentuan tenaga pengajar yang akan diterima bekerja dimana membutuhkan waktu yang lama dan ketika ada 2 (dua) pelamar yang nilainya sama dalam penentuan penilaiannya akan subjektif.

\section{Tujuan}

Adapun tujuan dari penelitian ini adalah :

a. Ingin membuktikan bahwa metode $S A W$ dapat diterapkan dalam rekomendasi tenaga pengajar.

b. Mendapatkan efektivitas proses dalam rekomendasi tenaga pengajar baru. 
c. Mengukur tingkat kelayakan penerapan $S A W$ kedalam bentuk aplikasi rekomendasi tenaga pengajar baru.

\section{Tinjauan Pustaka}

\section{a. Simple Additive Weighting (SAW)}

Menurut (S. Kusumadewi, 2003) metode $S A W$ adalah metode yang paling diketahui dan dipakai ketika menghadapi situasi Multiple Atribut Decision Making (MADM), dimana bobot dari setiap atribut ditentukan oleh pembuat keputusan. Untuk memperoleh skor total untuk pembuat alternatif maka dijumlahkanlah seluruh hasil perkalian antara rating tiap atribut, dimana harus bebas dimensi dan melewati proses normalisasi sebelumnya. Adapun rumus dalam melakukan normalisasi tersebut adalah (Saputra, K Harry dan Aprilian, 2020):

$$
R_{i j}= \begin{cases}\frac{X_{i j}}{\operatorname{Max}_{i}\left(X_{i j}\right)} & \text { Jika j adalah atribut keuntungan (benefit) } \\ \frac{\operatorname{Min}_{\mathrm{i}}\left(X_{i j}\right)}{X_{i j}} & \text { Jika j adalah atribut biaya (cost) }\end{cases}
$$

Dimana :

$\mathrm{R}_{\mathrm{i}} \quad$ : Rating kinerja ternormalisasi dari alternatif Ai pada atribut $\mathrm{C}_{\mathrm{j}}(\mathrm{i}=1,2 \ldots, \mathrm{m})$ dan $(\mathrm{j}=1,2 \ldots, \mathrm{n})$

$\operatorname{Max}_{\mathrm{i}} \quad$ : Nilai terbesar dari setiap kriteria $\mathrm{i}$

$\mathrm{X}_{\mathrm{ij}}$

$\operatorname{Min}_{\mathrm{i}} \quad$ : Nilai terkecil dari setiap kriteria i

$\mathrm{X}_{\mathrm{ij}}$

$\mathrm{X}_{\mathrm{ij}} \quad$ : Nilai atribut yang dimiliki dari setiap kriteria

Nilai preferensi bagi setiap alternatif $\left(\mathrm{V}_{\mathrm{i}}\right)$ adalah sebagai berikut:

$$
\mathrm{V}_{\mathrm{i}}=\sum_{j=1}^{n} \mathbf{W}_{\mathrm{j}} \mathrm{r}_{\mathrm{ij}}
$$

Dimana :

$\mathrm{V}_{\mathrm{i}} \quad$ : Nilai akhir dari alternatif

$\mathrm{W}_{\mathrm{j}} \quad$ : Bobot yang telah ditentukan

$\mathrm{r}_{\mathrm{ij}} \quad:$ Normalisasi matriks

\section{b. Pengelolaan Sumber Daya Manusia}

Menurut (Danumiharja, 2014) menjelaskan bahwa sumber daya manusia menjadi modal pertama dan utama dalam setiap lembaga apapun, terutama dalam lembaga pendidikan.

\section{B. METODE}

\section{Prosedur Pengembangan}

Dalam menghasilkan penelitian yang yang diharapkan, penyusun membuat prosedur pengembangan dengan pendekatan metode prototyping, sebagai berikut:

a. Analisa Permasalahan

Analisa permasalahan adalah tahap pertama dimana dengan wawancara akan mendapatkan informasi tentang permasalahan yang ada.

b. Desain Aplikasi

Desain aplikasi yaitu dilakukan untuk mengetahui rancangan aplikasi yang akan dikembangkan oleh penyusun.

c. Mengkodekan Sistem

Mengkodekan sistem yaitu proses mengartikan perancangan desain kedalam format bahasa pemrograman sehingga dapat dimengerti oleh mesin.

d. Menguji Sistem 
Volume 11 Number 2 November 2021 Page. 61-72

Journal Homepage : http://teknois.stikombinaniaga.ac.id/index.php/JBS

DOI Link : http://doi.org/10.36350/jbs.v11i2

Proses pengujian pada program perangkat lunak dilakukan setelah proses pengkodean selesai.

e. Evaluasi Sistem

Evaluasi sistem digunakan untuk menguji kegunaan sistem. Jika evaluasi sistem berhasil maka proses akan berlanjut ke tahap implementasi sistem. Akan tetapi, apabila tidak berhasil maka proses akan mengulang lagi dari tahap desain aplikasi.

f. Implementasi Sistem

Sistem yang telah dibuat akan diterapkan dan dipelihara.

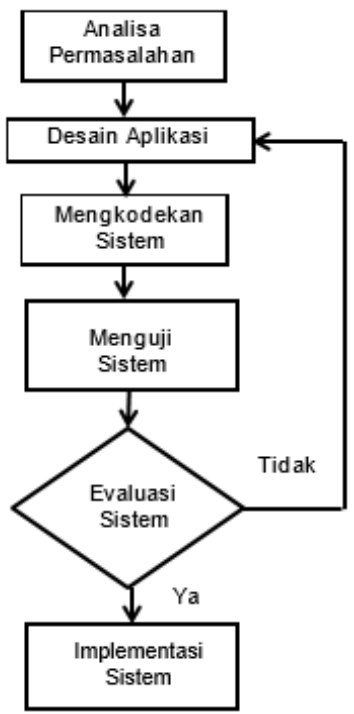

Gambar 1. Bagan Alur Prosedur Pengembangan

\section{Desain Ujicoba}

Desain uji coba yang penyusun lakukan pada penelitian ini adalah desain uji coba ahli dan pengguna. Uji cobanya dengan membuat sebuah aplikasi untuk membuktikan ketepatan pada penelitian ini. 2 (dua) ahli sistem mengisi kuesioner untuk uji coba ahli. Hal ini dilakukan untuk membuktikan ketepatan informasi dari hasil analisis. Sedangkan 16 (enam belas) pengguna mengisi kuesioner untuk uji coba pengguna untuk mengetahui apakah produk bisa digunakan oleh pengguna.

\section{Instrumen Penelitian}

a. Instrumen Untuk Ahli

Tabel 1. Instrumen Untuk Ahli

\begin{tabular}{|c|l|l|}
\hline No & \multicolumn{1}{|c|}{ Indikator } & \multicolumn{1}{c|}{ Deskripsi } \\
\hline 1. & Suitability & $\begin{array}{l}\text { Kemampuan perangkat lunak untuk menyediakan serangkaian } \\
\text { fungsi yang sesuai untuk tugas - tugas tertentu dan tujuan } \\
\text { pengguna }\end{array}$ \\
\hline 2. & Accuracy & $\begin{array}{l}\text { Kemampuan perangkat lunak dalam memberikan hasil yang } \\
\text { presisi dan benar sesuai dengan kebutuhan }\end{array}$ \\
\hline 3. & Security & $\begin{array}{l}\text { Kemampuan perangkat lunak untuk mencegah akses yang tidak } \\
\text { diinginkan, menghadapi penyusup (Hacker) maupun otoritas } \\
\text { dalam modifikasi data }\end{array}$ \\
\hline 5. & Interoperability & $\begin{array}{l}\text { Kemampuan perangkat lunak untuk berinteraksi dengan satu } \\
\text { atau lebih sistem tertentu }\end{array}$ \\
\hline 5. & Compliance & $\begin{array}{l}\text { Kemampuan perangkat lunak dalam memenuhi standar dan } \\
\text { kebutuhan sesuai peraturan yang berlaku }\end{array}$ \\
\hline 7. & Fauturity & $\begin{array}{l}\text { Kemampuan perangkat lunak untuk menghindari kegagalan } \\
\text { akibat dari kesalahan dalam P/ }\end{array}$ \\
\hline 8. & Recoverability & $\begin{array}{l}\text { Kemampuan perangkat lunak untuk mempertahankan } \\
\text { kinerjanya jika terjadi kesalahan perangkat lunak }\end{array}$ \\
\hline
\end{tabular}


Volume 11 Number 2 November 2021 Page. 61-72

Journal Homepage : http://teknois.stikombinaniaga.ac.id/index.php/JBS

DOI Link : http://doi.org/10.36350/jbs.v11i2

\begin{tabular}{|c|l|l|}
\hline 9. & Understandibility & Kemampuan perangkat lunak untuk di pahami \\
\hline 10. & Learnability & Kemampuan perangkat lunak untuk di pelajari \\
\hline 11. & Operability & $\begin{array}{l}\text { Kemampuan perangkat lunak dalam kemudahan untuk di } \\
\text { pelajari }\end{array}$ \\
\hline 12. & Attractiveness & Kemampuan perangkat lunak untuk menarik pengguna \\
\hline 13. & Time Behaviour & $\begin{array}{l}\text { Kemampuan perangkat lunak dalam memberikan respon dan } \\
\text { waktu pengolahan yang sesuai saat melakukan fungsinya }\end{array}$ \\
\hline 14. & Resource Behaviour & $\begin{array}{l}\text { Kemampuan perangkat lunak dalam menggunakan sumber daya } \\
\text { yang di milikinya ketika melakukan fungsi yang ditentukan }\end{array}$ \\
\hline 15. & Analyzability & $\begin{array}{l}\text { Kemampuan perangkat lunak dalam mendiagnosa kekurangan } \\
\text { atau penyebab kegagalan }\end{array}$ \\
\hline 16. & Changeability & Kemampuan perangkat lunak untuk dimodifikasi \\
\hline 17. & Stability & $\begin{array}{l}\text { Kemampuan perangkat lunak untuk meminimalkan efek tak } \\
\text { terduga dan memodifikasi perangkat lunak }\end{array}$ \\
\hline 18. & Testability & $\begin{array}{l}\text { Kemampuan perangkat lunak untuk memodifikasi dan } \\
\text { divalidasi perangkat lunak lain }\end{array}$ \\
\hline 19. & Adaptability & $\begin{array}{l}\text { Kemampuan perangkat lunak untuk diadaptasikan pada } \\
\text { lingkungan yang berbeda - beda }\end{array}$ \\
\hline 20. & Instability & $\begin{array}{l}\text { Kemampuan perangkat lunak untuk diinstal dalam lingkungan } \\
\text { yang berbeda - beda }\end{array}$ \\
\hline 21. & Coexistence & $\begin{array}{l}\text { Kemampuan perangkat lunak untuk berdampingan dengan } \\
\text { perangkat lunak lainnya dalam satu lingkungan dengan berbagai } \\
\text { sumber daya }\end{array}$ \\
\hline 22. & Replacebility & $\begin{array}{l}\text { Kemampuan perangkat lunak untuk digunakan sebagai } \\
\text { pengganti perangkat lunak lainnya }\end{array}$ \\
\hline
\end{tabular}

(sumber: ISO 9126)

b. Instrumen Untuk Pengguna

Tabel 2. Instrumen Untuk Pengguna

\begin{tabular}{|c|l|}
\hline No & \\
\hline 1. & Overall, I am satisfied with how easy it is to use this system \\
\hline 2. & It was simple to use this system \\
\hline 3. & I could effectively complete the tasks and scenarios using this system \\
\hline 4. & I was able to complete the tasks and scenarios quickly using this system \\
\hline 5. & I was able to efficiently complete the tasks and scenarios using this system \\
\hline 6. & I felt comfortable using this system \\
\hline 7. & It was easy to learn to use this system \\
\hline 8. & I believe I could become productive quickly using this system \\
\hline 9. & The system gave error messages that clearly told me how to fix problems \\
\hline 10. & Whenever I made a mistake using the system, I could recover easily and quickly \\
\hline 11. & $\begin{array}{l}\text { The information (such as on-line help, on-screen messages, and other documentation) } \\
\text { provided with this system was clear }\end{array}$ \\
\hline 12. & It was easy to find the information I needed \\
\hline 13. & The information provided for the system was easy to understand \\
\hline 14. & The information was effective in helping me complete the tasks and scenarios \\
\hline 15. & The organization of information in the system screen was clear \\
\hline 16. & The Interface of this system was pleasant \\
\hline 17. & I liked using the interface of this system \\
\hline 18. & This system has all the functions and capabilities I expect it to have \\
\hline 19. & Overall, I am satisfied with this system \\
\hline
\end{tabular}

\section{Teknik Analisa Data}

\section{a. Uji Produk}

Pengukuran usability dilakukan dengan menghitung persentase jawaban dari responden menggunakan rumus. Dalam penelitian ini, untuk uji produk penyusun memilih metode analisis data menggunakan persentase kelayakan yang rumusnya (Mies Grijns, Hoko Horii, Sulistyowati Irianto, Pinky Saptandari, Taufiqurrohim, Unsiyah Siti Marhamah, Meike Lusye Karolus, Shinta Candra Dwi, Partini, 2018): 
Volume 11 Number 2 November 2021 Page. 61-72

Journal Homepage : http://teknois.stikombinaniaga.ac.id/index.php/JBS

DOI Link : http://doi.org/10.36350/jbs.v11i2

$$
\text { Presentase }=\frac{f}{n} x 100 \%
$$

Dimana :

F adalah Jumlah jawaban yang dipilih responden

$\mathrm{n}$ adalah Jumlah skor maksimal

Data yang diperoleh dikonversi dengan menggunakan tabel kelayakan berikut ini (Hariadi, 2019):

Tabel 3 Kategori Kelayakan Menurut Arikunto

\begin{tabular}{|c|c|c|c|}
\hline Nilai & Persentase & Kualifikasi & Tindak Lanjut \\
\hline 4 & $85 \%-100 \%$ & Sangat Layak & Implementasi \\
\hline 3 & $75 \%-84 \%$ & Layak & Implementasi \\
\hline 2 & $55 \%-74 \%$ & Kurang Layak & Revisi \\
\hline 1 & $<55 \%$ & Tidak Layak & Revisi \\
\hline
\end{tabular}

(Sumber : Hariadi, 2019:15)

\section{b. Uji Hasil}

Untuk teknik uji hasil, penyusun memilih uji korelasi Spearman. Uji korelasi Spearman digunakan untuk menguji hipotesis asosiatif dua variabel bila datanya berskala ordinal (ranking). Adapun rumus uji korelasi Spearman sebagai berikut (Lind, A. Douglas, William G. Marchal, 2008):

$$
r s=1-\frac{6 \sum d^{2}}{n\left(n^{2}-1\right)}
$$

Dimana :

Rs adalah Koefisien Korelasi Spearman

$\sum \mathrm{d}^{2}$ adalah Total kuadrat selisih antar ranking

$\mathrm{n}$ adalah Jumlah sampel penelitian

\section{HASIL DAN PEMBAHASAN}

\section{Hasil}

\section{a. Analisa Kebutuhan Sistem}

Analisis kebutuhan sistem dengan melakukan perancangan sistem yang dikembangkan, dimana pemodelan objeknya dapat dilihat pada bentuk diagram use case dibawah ini.

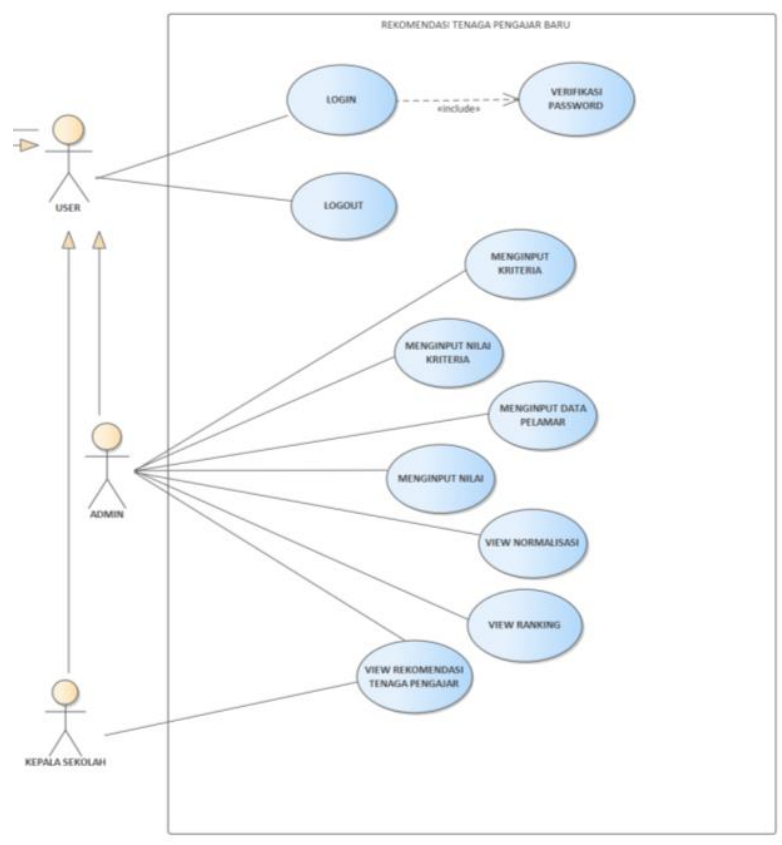

Gambar 2. Diagram Use Case 
Volume 11 Number 2 November 2021 Page. 61-72

Journal Homepage : http://teknois.stikombinaniaga.ac.id/index.php/JBS

DOI Link : http://doi.org/10.36350/jbs.v11i2

\section{b. Analisa Metode}

Dalam penelitian ini, penyusun menggunakan metode Simple Weighting additive (SAW), dimana nantinya akan menghasilkan perankingan untuk memutuskan tenaga pengajar yang akan diterima dan sebagai contoh penyusun menggunakan data pelamar tahun 2018 di sekolah Kinderfield Cibinong. Adapun langkah - langkah dalam metode $S A W$ :

\section{1) Penentuan Alternatif}

Pada Sekolah Kinderfield Cibinong ada 7 calon tenaga pengajar yang akan di hitung untuk menentukan tenaga pengajar yang akan di terima bekerja.

Tabel 4. Alternatif

\begin{tabular}{|l|c|}
\hline \multicolumn{2}{|c|}{ Alternatif / Calon karyawan } \\
\hline A1 & Pelamar A \\
\hline A2 & Pelamar B \\
\hline A3 & Pelamar C \\
\hline A4 & Pelamar E \\
\hline A5 & Pelamar H \\
\hline A6 & Pelamar J \\
\hline A7 & Pelamar K \\
\hline
\end{tabular}

\section{2) Penentuan Kriteria dan Bobot Tiap Kriteria}

Adapun bobot dan kriteria yang dibutuhkan dimana didapat dari hasil wawancara dengan kepala sekolah Kinderfield Cibinong sebagai berikut:

Tabel 5. Kriteria

\begin{tabular}{|c|c|c|c|}
\hline Kode & Kriteria & Jenis Kriteria & Bobot \\
\hline C1 & Pendidikan & Benefit & 15 \\
\hline C2 & Usia & Benefit & 10 \\
\hline C3 & Pengalaman kerja & Benefit & 15 \\
\hline C4 & Tempat tinggal & Cost & 5 \\
\hline C5 & Storytelling & Benefit & 15 \\
\hline C8 & Tes wawancara & Benefit & 20 \\
\hline C7 & Tes tertulis & Benefit & 10 \\
\hline C8 & Art & Benefit & 10 \\
\hline
\end{tabular}

\section{3) Menentukan rating kecocokan.}

Berikut rating kecocokan dari calon tenaga pengajar di Kinderfield Cibinong.

Tabel 6. Pelamar

\begin{tabular}{|c|c|c|c|c|c|c|c|c|}
\hline \multicolumn{10}{|c|}{ Kriteria } \\
\hline Alternatif & C1 & C2 & C3 & C4 & C5 & C6 & C7 & C8 \\
\hline A1 & 100 & 75 & 25 & 100 & 100 & 100 & 100 & 75 \\
\hline A2 & 100 & 100 & 50 & 75 & 100 & 100 & 100 & 75 \\
\hline A3 & 100 & 50 & 100 & 50 & 100 & 100 & 100 & 75 \\
\hline A4 & 75 & 75 & 25 & 50 & 75 & 75 & 75 & 75 \\
\hline A5 & 100 & 100 & 50 & 50 & 75 & 100 & 100 & 75 \\
\hline A6 & 100 & 75 & 50 & 100 & 100 & 100 & 100 & 75 \\
\hline A7 & 100 & 75 & 25 & 100 & 75 & 100 & 100 & 75 \\
\hline
\end{tabular}


Volume 11 Number 2 November 2021 Page. 61-72

Journal Homepage : http://teknois.stikombinaniaga.ac.id/index.php/JBS

DOI Link : http://doi.org/10.36350/jbs.v11i2

\section{4) Membuat Matriks Keputusan}

Nilai setiap alternatif dan kriteria yang sudah ditentukan diubah ke dalam matiks keputusan X.

$$
\mathbf{X}=\left[\begin{array}{cccccccc}
100 & 75 & 25 & 100 & 100 & 100 & 100 & 75 \\
100 & 100 & 50 & 75 & 100 & 100 & 100 & 75 \\
100 & 50 & 100 & 50 & 100 & 100 & 100 & 75 \\
75 & 75 & 25 & 50 & 75 & 75 & 75 & 75 \\
100 & 100 & 50 & 50 & 75 & 100 & 100 & 75 \\
100 & 75 & 50 & 100 & 100 & 100 & 100 & 75 \\
100 & 75 & 25 & 100 & 75 & 100 & 100 & 75
\end{array}\right]
$$

\section{5) Normalisasi Matriks Keputusan}

Berdasarkan preferensi dari nilai tertinggi, maka hasil perangkingan calon tenaga pengajar dapat dilihat pada tabel 7.

Tabel 7. Normalisasi Matrik X

\begin{tabular}{|c|c|c|c|c|c|c|c|c|}
\hline \multirow{2}{*}{ No } & \multicolumn{7}{|c|}{ Kriteria } \\
\cline { 2 - 10 } & C1 & C2 & C3 & C4 & C5 & C6 & C7 & C8 \\
\hline A1 & 1 & 0,75 & 0,25 & 0,5 & 1 & 1 & 1 & 1 \\
\hline A2 & 1 & 1 & 0,5 & 0,67 & 1 & 1 & 1 & 1 \\
\hline A3 & 1 & 0,5 & 1 & 1 & 1 & 1 & 1 & 1 \\
\hline A4 & 0,75 & 0,75 & 0,25 & 1 & 0,75 & 0,75 & 0,75 & 1 \\
\hline A5 & 1 & 1 & 0,5 & 1 & 0,75 & 1 & 1 & 1 \\
\hline A6 & 1 & 0,75 & 0,5 & 0,5 & 1 & 1 & 1 & 1 \\
\hline A7 & 1 & 0,75 & 0,25 & 0,5 & 0,75 & 1 & 1 & 1 \\
\hline
\end{tabular}

Kemudian ditranformasikan kedalam matriks sebagai berikut:

$$
\mathbf{R}=\left[\begin{array}{cccccccc}
1 & 0,75 & 0,25 & 0,5 & 1 & 1 & 1 & 1 \\
1 & 1 & 0,5 & 0,67 & 1 & 1 & 1 & 1 \\
1 & 0,5 & 1 & 1 & 1 & 1 & 1 & 1 \\
0,75 & 0,75 & 0,25 & 1 & 0,75 & 0,75 & 0,75 & 1 \\
1 & 1 & 0,5 & 1 & 0,75 & 1 & 1 & 1 \\
1 & 0,75 & 0,5 & 0,5 & 1 & 1 & 1 & 1 \\
1 & 0,75 & 0,25 & 0,5 & 0,75 & 1 & 1 & 1
\end{array}\right]
$$

\section{6) Menghitung Nilai Akhir Tiap Alternatif (Perangkingan)}

Proses perangkingan diperoleh dari persamaan Matriks Normalisasi (R) dengan Bobot Preferensi $(\mathrm{W})$ dimana $\mathrm{W}=[15 ; 10 ; 15 ; 5 ; 15 ; 20 ; 10 ; 10]$. Adapun hasilnya yaitu:

\begin{tabular}{|c|c|c|c|c|c|c|c|c|c|}
\hline \multirow[b]{2}{*}{ No } & \multicolumn{8}{|c|}{ Kriteria } & \multirow[b]{2}{*}{ Hasil } \\
\hline & C1 & C2 & $\mathrm{C} 3$ & C4 & C5 & c6 & C7 & C8 & \\
\hline A1 & 0,15 & 0,075 & 0,375 & 0,025 & 0,15 & 0,2 & 0,1 & 0,1 & 1,175 \\
\hline A2 & 0,15 & 0,1 & 0,075 & 0,0335 & 0,15 & 0,2 & 0,1 & 0,1 & 1,21 \\
\hline A3 & 0,15 & 0,05 & 0,15 & 0,05 & 0,15 & 0,2 & 0,1 & 0,1 & 0,95 \\
\hline A4 & 0,1125 & 0,075 & 0,0375 & 0,05 & 0,1125 & 0,15 & 0,075 & 0,1 & 1,05 \\
\hline A5 & 0,15 & 0,1 & 0,075 & 0,05 & 0,1125 & 0,2 & 0,1 & 0,1 & 0,8875 \\
\hline A6 & 0,15 & 0,075 & 0,075 & 0,025 & 0,15 & 0,2 & 0,1 & 0,1 & 0,875 \\
\hline A7 & 0,15 & 0,075 & 0,0375 & 0,025 & 0,1125 & 0,2 & 0,1 & 0,1 & 0,8 \\
\hline
\end{tabular}

Tabel 8. Hasil Perankingan 
Volume 11 Number 2 November 2021 Page. 61-72 Journal Homepage : http://teknois.stikombinaniaga.ac.id/index.php/JBS

DOI Link : http://doi.org/10.36350/jbs.v11i2

Berdasarkan preferensi dari nilai tertinggi, maka hasil perangkingan calon tenaga pengajar dapat dilihat pada tabel 9.

Tabel 9. Perangkingan

\begin{tabular}{|c|c|c|}
\hline No & Pelamar & Hasil \\
\hline 1 & Pelamar C & 95 \\
\hline 2 & Pelamar B & 90,85 \\
\hline 3 & Pelamar H & 88,75 \\
\hline 4 & Pelamar J & 87,5 \\
\hline 5 & Pelamar A & 83,75 \\
\hline 6 & Pelamar K & 80 \\
\hline 7 & Pelamar E & 71,25 \\
\hline
\end{tabular}

\section{c. Produk}

1) Form Input Data Kriteria

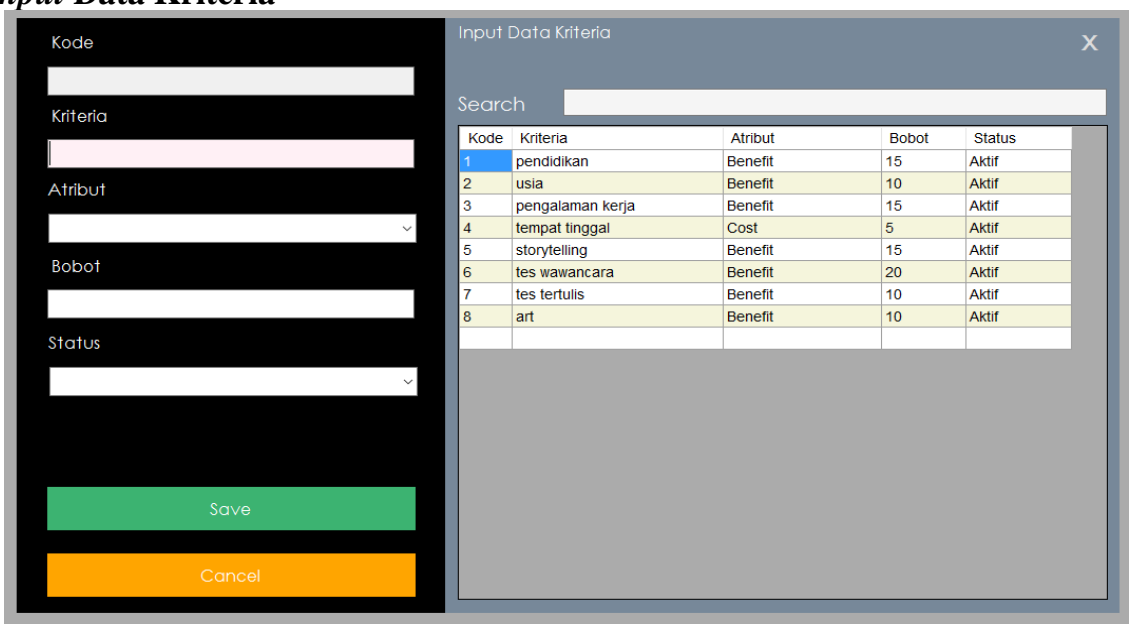

Gambar 3 Form Input Data Kriteria

Form kriteria dapat diakses oleh admin sehingga admin dapat menginput kriteria apa sajakah yang akan digunakan beserta atribut dan bobotnya masing - masing.

2) Form Input Nilai Kriteria (Crips)

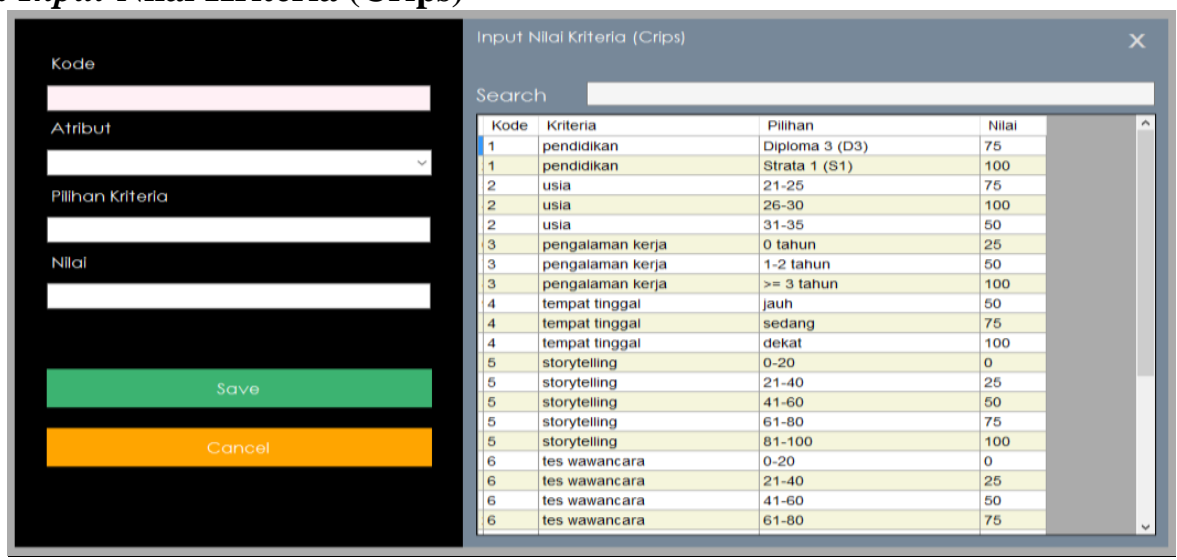

Gambar 4 Form Nilai Kriteria (Crips)

Form nilai kriteria dapat diakses oleh admin sehingga admin dapat menginput nilai dan bobot setiap kriteria yang akan digunakan berdasarkan tingkat kepentingan.

3) Proses Normalisasi 
Volume 11 Number 2 November 2021 Page. 61-72 Journal Homepage : $\underline{\text { http://teknois.stikombinaniaga.ac.id/index.php/JBS }}$ DOI Link : http://doi.org/10.36350/jbs.v11i2

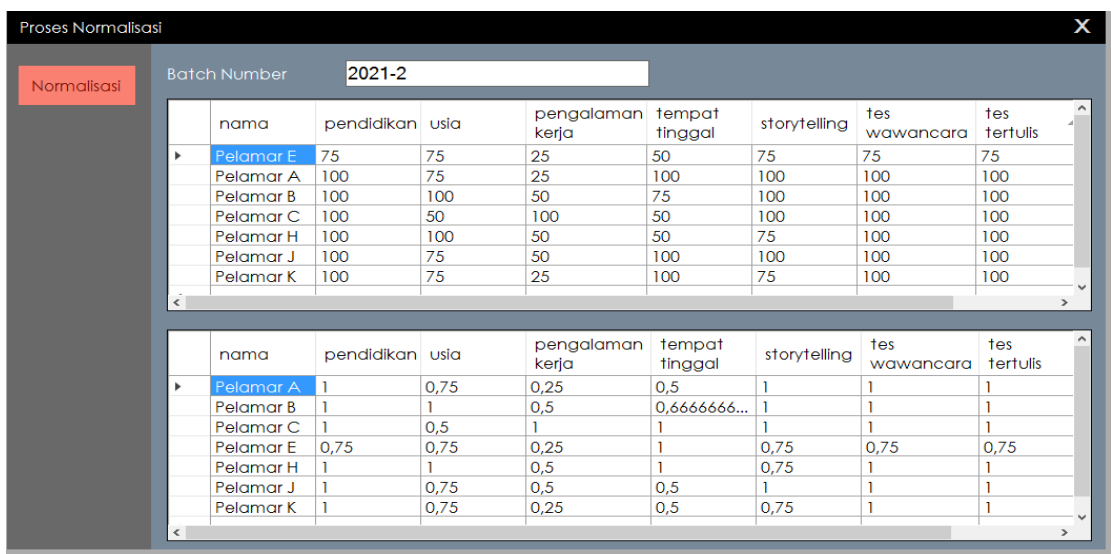

Gambar 5. Proses Normalisasi

Proses normalisasi dapat diakses oleh admin sehingga admin akan mendapatkan nilai normalisasi yang sudah disesuaikan berdasarkan jenis atributnya

\section{4) Proses Perankingan}

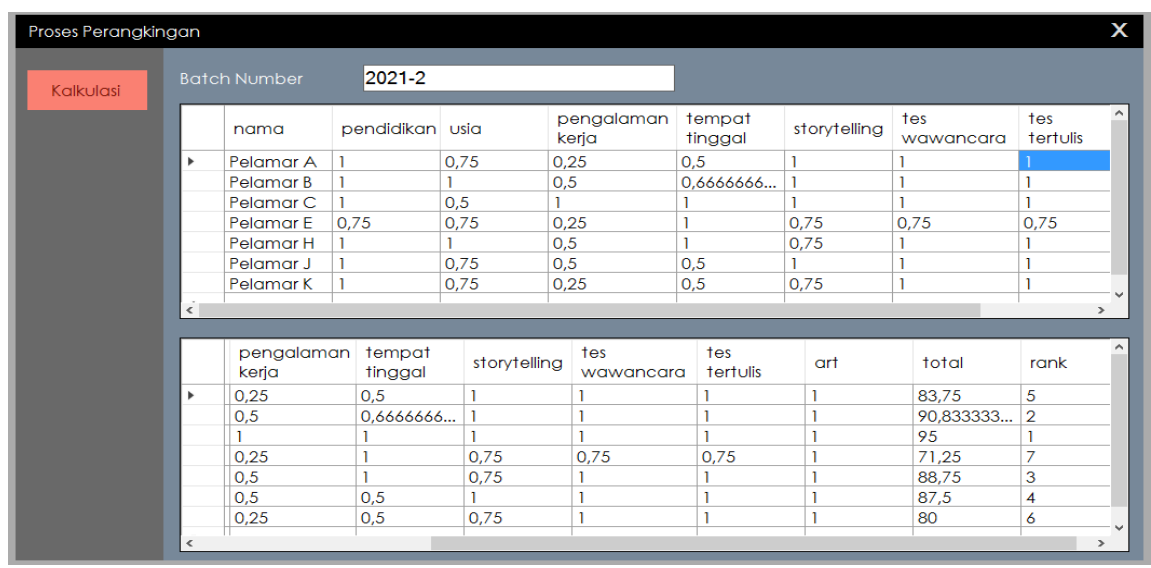

Gambar 6. Proses Perankingan

Proses perangkingan dapat diakses oleh admin sehingga admin akan mendapatkan total nilai yang diproleh berdasarkan persamaan normalisasi dengan bobot preferensi yang sudah ditentukan sehingga menghasilkan total nilai yang akan memperlihatkan hasil ranking.

5) View Laporan

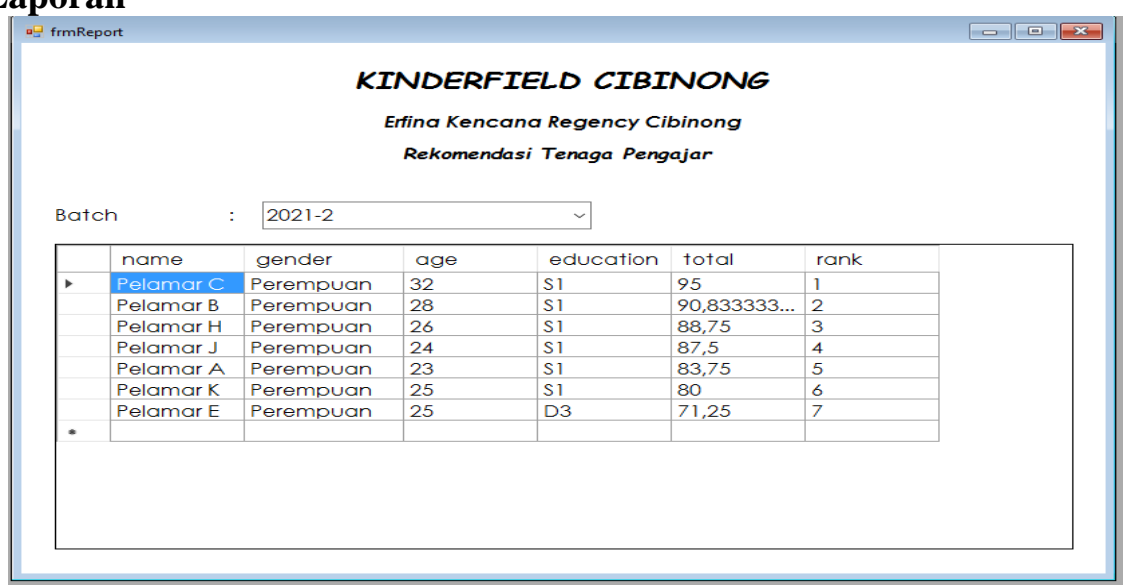

Gambar 7. View Laporan

View laporan dapat diakses oleh kepala sekolah (kepsek) sehingga kepala sekolah akan dapat melihat data berupa keterangan ranking untuk rekomendasi tenaga pengajar.

\section{Pembahasan}


a. Hasil Uji Coba Ahli

Hasil dari persentase kelayakan diperoleh sebesar $100 \%$ maka dapat dikategorikan "Sangat Layak" Kuesioner ini disertai pendapat tentang sistem secara keseluruhan (saran pengembangan) dimana akan dijadikan bahan evaluasi untuk sistem yang dikembangkan.

b. Hasil Kuesioner Pengguna

Berdasarkan hasil dari perhitungan persentase kelayakan untuk overall, sysuse, dan infoqual yang memperoleh nilai $86 \%, 89 \%$, dan $85 \%$ maka berada pada nilai tiap kriteria 4 (empat) dengan persentase $85 \%$ - 100\% sehingga sistem tersebut adalah memiliki kualifikasi sangat layak untuk diimplementasikan. Sedangkan untuk interqual memperoleh nilai $84 \%$ berada pada nilai tiap kriteria 3 (tiga) dengan persentase $75 \%$ $84 \%$ memiliki kualitas layak dan dapat diimplementasikan.

c. Uji Hasil

Uji hasil pada pengembangan penelitian ini adalah membandingkan hasil sebelum dan setelah menggunakan $S A W$. Perbandingan hasil ini menggunakan korelasi Spearman rank.

Tabel. Perhitungan Korelasi Spearman

\begin{tabular}{|c|c|c|c|c|}
\hline \multirow{2}{*}{ Alternatif } & \multirow{2}{*}{$\mathbf{X}$} & $\mathbf{Y}$ & $\mathbf{d}$ & $\mathbf{( d )}^{\mathbf{2}}$ \\
\cline { 4 - 5 } & & & $\mathbf{X}-\mathbf{Y}$ & $(\mathbf{X}-\mathbf{Y})^{2}$ \\
\hline Pelamar C & 2 & 1 & 1 & 1 \\
\hline Pelamar B & 4 & 2 & 2 & 4 \\
\hline Pelamar H & 5 & 3 & 2 & 4 \\
\hline Pelamar J & 1 & 4 & -3 & 9 \\
\hline Pelamar A & 3 & 5 & -2 & 4 \\
\hline Pelamar K & 6 & 6 & 0 & 0 \\
\hline Pelamar E & 7 & 7 & 0 & 0 \\
\hline \multicolumn{2}{|c|}{ Jumlah } & & $\Sigma d^{2}$ & 22 \\
\hline
\end{tabular}

Keterangan:

$\mathrm{X}=$ Peringkat sebelum penerapan metode

$\mathrm{Y}=$ Peringkat setelah penerapan metode

Selanjutnya dihitung dengan menggunakan korelasi spearman, yaitu:

$$
\begin{aligned}
& r s=1-\frac{6 \sum d^{2}}{n\left(n^{2}-1\right)} \\
& r s=1-\frac{6(22)}{7\left(7^{2}-1\right)} \\
& r s=1-\frac{132}{336} \\
& r s=1-0,39 \\
& r s=0,61
\end{aligned}
$$

Uji korelasi spearman rank menggunakan uji Z karena distribusinya mendekati distribusi normal (Sugiyono, 2019).

Tabel Uji Signifikansi Spearman Rank 
Volume 11 Number 2 November 2021 Page. 61-72

Journal Homepage : http://teknois.stikombinaniaga.ac.id/index.php/JBS

DOI Link : http://doi.org/10.36350/jbs.v11i2

\begin{tabular}{|c|c|}
\hline Nilai & Keterangan \\
\hline $0,00-0,199$ & Sangat Rendah \\
\hline $0,20-0,399$ & Rendah \\
\hline $0,40-0,599$ & Sedang \\
\hline $0,60-0,799$ & Kuat \\
\hline $0,80-1,000$ & Sangat Kuat \\
\hline
\end{tabular}

Dari hasil rs diperoleh nilai 0,61 dan berdasarkan perhitungan korelasi spearman rank, maka nilai termasuk kedalam kategori kuat yang memiliki makna bahwa terjadi perubahan antara sebelum dan sesudah menggunakan Simple Additive Weighting (SAW).

\section{KESIMPULAN}

Dari uraian penelitian dan pembahasan yang telah dilakukan, maka dapat diambil kesimpulan:

1. Metode $S A W$ dapat diterapkan dalam rekomendasi tenaga pengajar.

2. Dengan adanya variable/kriteria pendidikan, usia, pengalaman kerja, tempat tinggal, storytelling, tes wawancara, tes tertulis, dan art pada sistem, membantu dalam keputusan penerimaan tenaga pengajar Sekolah Tk Nasional Plus

3. Pengembangan prototype untuk pemodelan komputasi $S A W$ untuk rekomendasi tenaga pengajar menjadi lebih efektif.

4. Dengan adanya sistem ini, didapatkan hasil uji sistem yang diberikan oleh responden ahli dimana diperoleh nilai sebesar $100 \%$ atau berada pada kategori sangat layak untuk diimplementasikan, sedangkan hasil uji coba pada responden pengguna diperoleh nilai sebesar $87 \%$ dan berada pada kategori sangat layak. Berdasarkan hasil uji coba pada responden ahli dan pengguna maka sistem ini sangat layak untuk diimplementasikan

5. Dengan hasil perhitungan korelasi spearman rank yaitu 0,61 , maka nilai termasuk kedalam kategori kuat.

\section{E. DAFTAR PUSTAKA}

[1] Dzulhaq, M. I., \& Wulandari, S. (2017). Sistem Pendukung Keputusan Penerimaan Siswa Baru dengan Metode Simple Additive Weighting di SMK Kusuma Bangsa. 7(2).

[2] Fruhling, A., \& Lee, S. (2005). Assessing the reliability, validity and adaptability of PSSUQ. Association for Information Systems - 11th Americas Conference on Information Systems, AMCIS 2005: A Conference on a Human Scale, 5, 2231-2239.

[3] Kusumadewi, S. dan P. H. (2013). Aplikasi Logika Fuzzy Untuk Pendukung Keputusan (2nd Editio). Graha Ilmu.

[4] Lind, A. Douglas, William G. Marchal, S. A. W. (2008). Teknik - Teknik Statistik dalam Bisnis dan Ekonomi 2 (13th ed). Salemba Empat.

[5] Punaji, S. (2016). Metode Penelitian Pendidikan dan Pengembangan (4th ed). Prenadamedia Group.

[6] Sauro, J., \& Lewis, J. R. 1953-T. A.-T. T.-. (2016). Quantifying the user experience: practical statistics for user research $\mathrm{LK}$

[7] Seran, S. (2020). Metodologi Penelitian Ekonomi Dan Sosial. CV Budi Utama

[8] Sugiyono. (2017). Metode Penelitian Kuantitatif, Kualitatif, Dan R\&D (Cetakan Ke). Alfabeta.

[9] Van Blerkom, M. L. (2009). Measurement and Statistics for Teachers. hhtp://doi.org/10. $4324 / 9781315464770$

[10] Warmansyah, J. (2020). Metode Penelitian dan Pengolahan Data. CV Budi Utama 